\title{
Meta-Analysis the Effect of Asthma Comorbidity on the Mortality of COVID-19 Patients
}

\author{
Siti Mar'atul Munawaroh'), Hanung Prasetya'), Bhisma Murti1) \\ ${ }^{1)}$ Masters Program in Public Health, Universitas Sebelas Maret \\ ${ }^{2)}$ Health Polytechnics, Ministry of Health Surakarta
}

\section{ABSTRACT}

Background: COVID-19 is an infectious disease that spread throughout the world in December 2019. The risk factors for mortality of COVID-19 patients depend on comorbid diseases. Most of the comorbid diseases associated with COVID-19 deaths consist of hypertension, diabetes, obesity, cardiovascular disease, chronic obstructive pulmonary disease, chronic kidney disease, and asthma. This study aims to analyze the effect of comorbid asthma on mortality in COVID-19 patients.

Subjects and Method: This was a meta-analysis study using PRISMA flowchart guidelines. The article search process was carried out between 2020-2021 using databases from PubMed, Google Scholar and Scopus. Based on the database, there were 15 articles that met the inclusion criteria. The analysis was carried out using the RevMan 5.3 software.

Results: The 15 articles reviewed in the meta-analysis showed that comorbid asthma increased the mortality risk of COVID-19 patients and was statistically significant $(\mathrm{aOR}=1.18$; $\mathrm{CI} 95 \%=1.02$ to $1.36 ; \mathrm{p}=0.030$ ).

Conclusion: Asthma comorbidities increase the mortality of COVID-19 patients.

Keywords: Asthma, mortality, COVID-19, SARS-CoV 2

\section{Correspondence:}

Siti Mar'atul Munawaroh. Masters Program in Public Health, Universitas Sebelas Maret. Jl. Ir. Sutami 36A, Surakarta 57126, Central Java. Email: sitimaratulo8@gmail.com. Mobile: +62 8213329-5468.

Cite this as:

Munawaroh SM, Prasetya H, Murti B (2021). Meta-Analysis the Effect of Asthma Comorbidity on the Mortality of COVID-19 Patients. J Epidemiol Public Health. 06(02): 256-267. https://doi.org/10.26911/jepublichealth.2021.06.02.12

cc) (i) (2) Journal of Epidemiology and Public Health is licensed under a Creative Commons Attribution-NonCommercial-ShareAlike 4.0 International License

\section{BACKGROUND}

COVID-19 is an infectious disease that spread throughout the world in December 2019 (Huang, et al., 2020). Update on COVID-19 cases as of July 16, 2021, there are $188,655,968$ confirmed cases of COVID19 worldwide, including 4,067,517 deaths (WHO, 2020). COVID-19 is caused by Severe Acute Respiratory Syndrome Coronavirus 2 (SARS-CoV-2). Common symptoms of COVID-19 infection include fever
(83\%-98\%), cough (50\%-82\%), fatigue (25\%-44\%), shortness of breath (19\%-55\%), and muscle aches (11\%-44\%) (Chen et al., 2020).

Risk factors for mortality in COVID19 patients include age, presence of comorbid diseases, secondary infection, and increased blood levels of inflammatory indicators (Ruan et al., 2020). Most of the comorbid diseases associated with COVID19 mortality consist of hypertension (Sun et 
al., 2020; Grasselli, et al., 2020), diabetes (Sticchi et al., 2021; Corcoles et al., 2020; Charoenngam et al., 2021), obesity (Kurniawati et al., 2021; Kim et al., 2021) cardiovascular disease (Shi et al., 2020), cerebrovascular disease (Fang et al., 2020), chronic obstructive pulmonary disease (Kar et al., 2021), cardiac injury disease (Song et al., 2020), and chronic kidney disease (La-Pena et al., 2020; Williamson et al., 2020).

The American Academy of Allergy, Asthma \& Immunology considers asthma a risk factor for COVID-19 (CDC, 2020; Abrams et al., 2020). Several studies in China reported underlying respiratory disease as a comorbidity among hospitalized patients with COVID-19 (Zhou et al., 2020; Huang et al., 2020; $\mathrm{Xu}$ et al., 2020; Li et al., 2020; Zhang et al., 2020) with some specifically mentioning asthma.

Based on the large number of COVID19 cases that afflict asthmatic patients and the need for appropriate prevention and treatment, researchers are interested in conducting a meta-analysis of the effect of asthma comorbidities on mortality of COVID-19 patients. This study aims to analyze the effect of comorbid asthma on mortality of COVID-19 patients in hospital, with a meta-analysis of previously conducted primary studies.

\section{SUBJECTS AND METHOD}

\section{Study Design}

This research was conducted using a metaanalysis research design with PRISMA flow chart guidelines. Article searches were performed using the following databases: PubMed, Google Scholar and Scopus. Some of the keywords used were: "asthma AND (Mortality OR Death) AND COVID-19 OR SARS-CoV-2.".

\section{Inclusion Criteria}

The inclusion criteria for this research article were full paper cohort study articles, articles using English, adjusted Odds Ratio (aOR) relationship size, COVID-19 patient subjects, patient mortality outcomes.

\section{Exclusion Criteria}

The exclusion criteria for this research article were the statistical results of bivariate analysis, and articles that did not use English.

\section{Operational Definition}

Articles included in this study are PICOadjusted. The article search was carried out taking into account the eligibility criteria determined using the following PICO model: Population $=$ COVID-19 patients, Intervention = asthma comorbidity, Comparison $=$ no asthma comorbidity, Outcome $=$ mortality.

Asthma is a chronic inflammatory airway disease characterized by wheezing, coughing, and tightness in the chest due to airway obstruction, and belongs to the group of chronic respiratory diseases. Asthma is categorized as asthmatic and non-asthmatic. The measurement scale is categorical.

Mortality is determined by the status of death in patients diagnosed with COVID19. Mortality was categorized as dead and alive. The measurement scale is categorical.

\section{Instrument Study}

Research is guided by the PRISMA flow diagram and assessment of the quality of research articles using the Critical Appraisal Skills Program tool (CASP, 2018). The 12 questions used are as follows:

1. Did the study address a clearly focused issue?

2. Was the cohort recruited in an acceptable way?

3. Was the exposure COVID-19 accurately measured to minimize bias?

4. Was the outcome (status mortality) accurately measured to minimize bias?

5. Have the authors identified allimportant confounding factors? Have the authors took account of the 
Munawaroh et al./ Effect of Asthma Comorbidity on the Mortality of COVID-19 Patients

confounding factors in the design and/or analysis?

6. Was the follow-up of subjects complete enough? Was the follow-up of subjects long enough?

7. Was the result of this study reported in aOR?

8. How precise were the results?

\section{Data Analysis}

Research data were analyzed using the RevMan 5.3 application, to calculate the effect size and heterogeneity of the study. The results of data processing are presented in the form of forest plots and funnel plots.
9. Do you believe the results?

10. Can the results be applied to the local population?

11. Do the results of this study fit with other available evidence?

12. What are the implications of this study for practice?

\section{RESULTS}

The article review process using the PRISMA flowchart can be seen in Figure 1. The total articles obtained were 10 articles spread across 4 continents, namely America, Europe, Asia and Africa.

\begin{tabular}{|c|c|}
\hline $\begin{array}{l}\text { Articles identified through database } \\
\text { search }(\mathrm{n}=1,319)\end{array}$ & Remove duplicate articles $(n=28)$ \\
\hline$\downarrow$ & \multirow{3}{*}{$\begin{array}{l}\text { Records excluded }(n=881) \\
\text { 1. Irrelevant title }=623 \\
\text { 2. Articles not observasional study }=214 \\
\text { 3. Articles not in English }=8 \\
\text { 4. Article not full text }=36\end{array}$} \\
\hline Filtered articles $(n=881)$ & \\
\hline$\downarrow$ & \\
\hline $\begin{array}{l}\text { Full text articles that are considered } \\
\text { eligible }(n=64)\end{array}$ & \multirow{3}{*}{$\begin{array}{l}\text { Full text articles issued, with reasons }(n=49) \\
\text { 1. Articles are not logistic regression }=12 \\
\text { 2. Effect measured other than aOR }(\mathrm{aRR} / \\
\text { aHR })=13 \\
\text { 3. Outcome not death }=24\end{array}$} \\
\hline 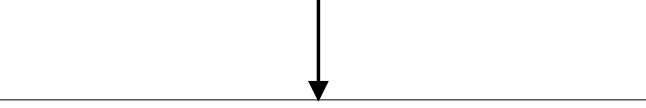 & \\
\hline Articles included in the $n$ & \\
\hline
\end{tabular}

Figure 1. PRISMA flowchart

Tabel 1. The Quality Assessment of the Cohort Study on Effect of Asthma Comorbidity on Mortality of COVID-19 Patients

\begin{tabular}{|c|c|c|c|c|c|c|c|c|c|c|c|c|c|}
\hline \multirow[t]{2}{*}{ Primer Study } & \multicolumn{12}{|c|}{ Criteria } & \multirow[t]{2}{*}{ Total } \\
\hline & $\mathbf{1}$ & 2 & 3 & 4 & 5 & 6 & 7 & 8 & 9 & 10 & 11 & 12 & \\
\hline Almazeedi et al. (2020) & 2 & 2 & 2 & 2 & 2 & 2 & 2 & 1 & 2 & 2 & 2 & 2 & 23 \\
\hline Almirall et al. (2020) & 2 & 2 & 2 & 2 & 2 & 2 & 2 & 2 & 2 & 2 & 2 & 2 & 24 \\
\hline Choi et al. (2020) & 2 & 2 & 2 & 2 & 2 & 2 & 2 & 2 & 2 & 2 & 2 & 2 & 24 \\
\hline Cummins et al. (2021) & 2 & 2 & 2 & 2 & 2 & 2 & 2 & 2 & 2 & 2 & 2 & 2 & 24 \\
\hline Ken-Dror et al. (2020) & 2 & 2 & 2 & 2 & 2 & 2 & 2 & 2 & 2 & 2 & 2 & 2 & 24 \\
\hline Lee et al. (2020) & 2 & 2 & 2 & 2 & 2 & 2 & 2 & 2 & 2 & 2 & 2 & 2 & 24 \\
\hline Lohia et al. (2021) & 2 & 2 & 2 & 2 & 2 & 2 & 2 & 2 & 2 & 2 & 2 & 2 & 24 \\
\hline Mulhem et al. (2020) & 2 & 2 & 2 & 2 & 2 & 2 & 2 & 2 & 2 & 2 & 2 & 2 & 24 \\
\hline Osibogun et al. (2021) & 2 & 2 & 2 & 2 & 2 & 2 & 2 & 2 & 2 & 2 & 2 & 2 & 24 \\
\hline Park et al. (2020) & 2 & 2 & 2 & 2 & 2 & 2 & 2 & 2 & 2 & 2 & 2 & 2 & 24 \\
\hline Robles-Perez et al. (2021) & 2 & 2 & 2 & 2 & 2 & 2 & 2 & 2 & 2 & 2 & 2 & 2 & 24 \\
\hline Rosa et al. (2021) & 2 & 2 & 2 & 2 & 2 & 2 & 2 & 2 & 2 & 2 & 2 & 2 & 24 \\
\hline Shin et al. (2021) & 2 & 2 & 2 & 2 & 2 & 2 & 2 & 2 & 2 & 2 & 2 & 2 & 24 \\
\hline Toples et al. (2021) & 2 & 2 & 2 & 2 & 2 & 2 & 2 & 2 & 2 & 2 & 2 & 2 & 24 \\
\hline Trabulus et al. (2021) & 2 & 2 & 2 & 2 & 2 & 2 & 2 & 1 & 2 & 2 & 2 & 2 & 23 \\
\hline
\end{tabular}

Note: Answer 2= Yes; Answer 1= Can't tell; Answer $0=$ No 


\section{a. Forest plot}

The forest plot in Figure 2 shows that COVID-19 patients with comorbid asthma have a mortality risk of 1.18 times compa- red to COVID-19 patients without comorbid asthma and the results are statistically significant $(\mathrm{aOR}=1.18 ; \mathrm{CI} 95 \%=1.02$ to $1.36 ; \mathrm{p}=0.030)$.

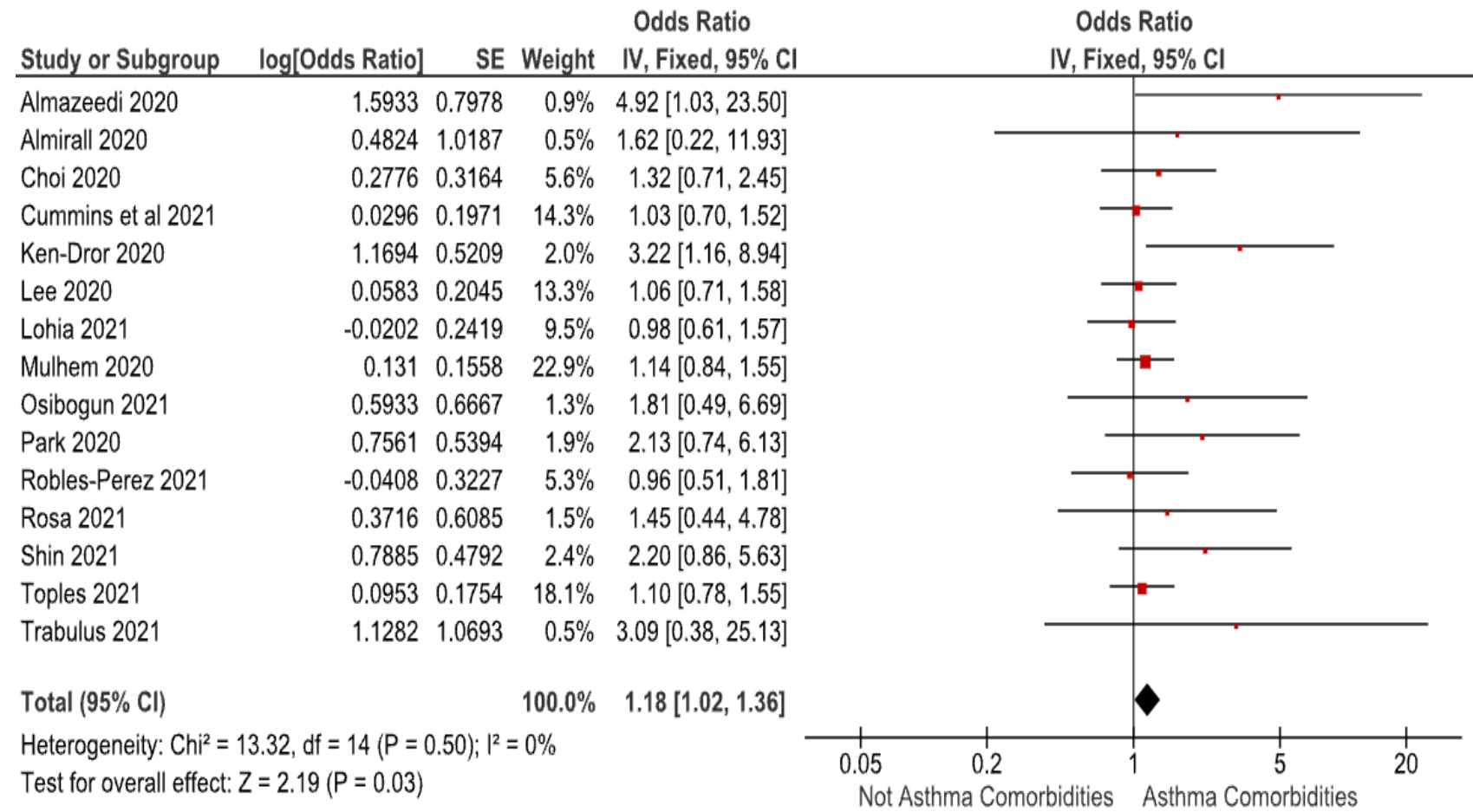

Figure 2. Forest plot Effect of Asthma Comorbidity on Mortality of COVID-19 Patients

\section{b. Funnel plot}

The funnel plot in Figure 3 shows publication bias with an overestimated effect characterized by an asymmetric distribution between the right and left plots. There are 9 plots on the right, 5 plots on the left, and 1 plot touching the vertical line. The plot on the right of the graph appears to have a standard error (SE) between $o$ and 1.50. The plot on the left of the graph appears to have a standard error (SE) between 0 and 0.50 .

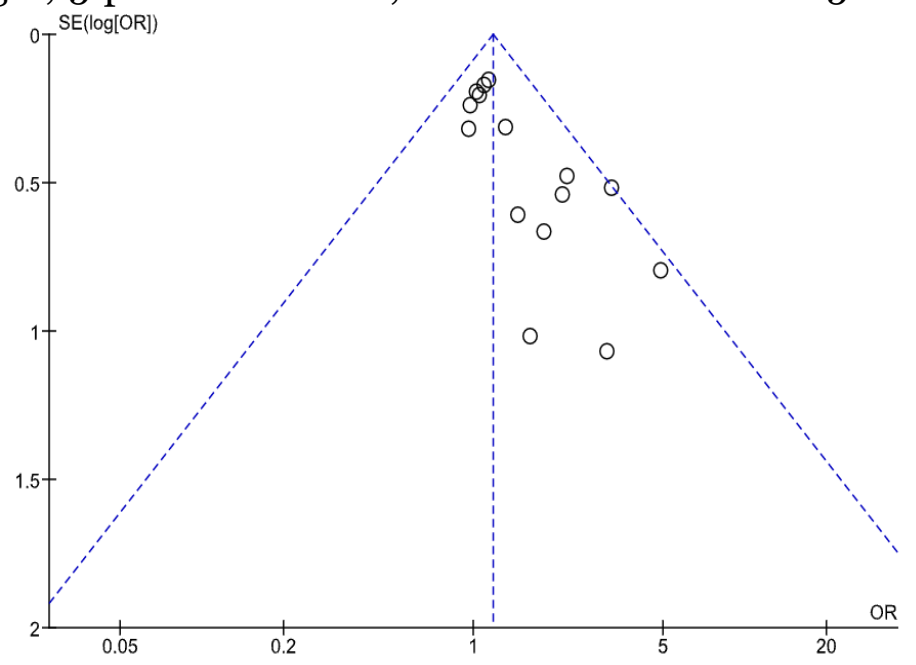

Figure 3. Funnel Plot Effect of Asthma Comorbidity on Mortality of COVID-19 Patients 
Munawaroh et al./ Effect of Asthma Comorbidity on the Mortality of COVID-19 Patients

Table 2. Description of the primary studies included in the meta-analysis

\begin{tabular}{|c|c|c|c|c|c|c|c|c|c|c|}
\hline \multirow{2}{*}{$\begin{array}{l}\text { Author } \\
\text { (Year) }\end{array}$} & \multirow{2}{*}{$\begin{array}{l}\text { Study } \\
\text { Period }\end{array}$} & \multirow[t]{2}{*}{ Country } & \multirow{2}{*}{$\begin{array}{c}\text { Study } \\
\text { Design }\end{array}$} & \multicolumn{2}{|c|}{ Sample Size } & \multirow{2}{*}{$\begin{array}{c}\mathbf{P} \\
\text { (Population) }\end{array}$} & \multirow{2}{*}{$\begin{array}{c}\text { I } \\
\text { (Intervention) }\end{array}$} & \multirow{2}{*}{$\begin{array}{c}\mathrm{C} \\
\text { (Comparison) }\end{array}$} & \multirow{2}{*}{$\begin{array}{c}\mathrm{O} \\
\text { (Outcome) }\end{array}$} & \multirow{2}{*}{$\begin{array}{c}\text { aOR } \\
(\mathrm{CI} 95 \%)\end{array}$} \\
\hline & & & & Total & $\begin{array}{c}\text { Asma } \\
\text { (\%) }\end{array}$ & & & & & \\
\hline $\begin{array}{l}\text { Almazeed } \\
\text { i et al. } \\
(2020)\end{array}$ & $\begin{array}{l}24 \text { February } \\
\text { to } 20 \text { April } \\
2020\end{array}$ & Kuwait & $\begin{array}{l}\text { Retrospective } \\
\text { cohort }\end{array}$ & 1,096 & $\begin{array}{c}43 \\
(3.9)\end{array}$ & $\begin{array}{l}\text { Adult patients aged } \\
25-75 \text { years } \\
\text { confirmed COVID-19 }\end{array}$ & $\begin{array}{l}\text { Obesity, Diabetes } \\
\text { mellitus, hypertensi, } \\
\text { chronic kidney failure, } \\
\text { and asthma }\end{array}$ & $\begin{array}{l}\text { Without } \\
\text { comorbid } \\
\text { asthma }\end{array}$ & Mortality & $\begin{array}{l}\mathrm{aOR}=4.92 \\
(1.03 \text { to } \\
23.44)\end{array}$ \\
\hline $\begin{array}{l}\text { Almirall } \\
\text { et al. } \\
(2020)\end{array}$ & $\begin{array}{l}29 \text { February } \\
\text { to } 4 \text { April } \\
2020\end{array}$ & Spanish & $\begin{array}{l}\text { Retrospective } \\
\text { cohort }\end{array}$ & 486 & $\begin{array}{c}13 \\
(4.0)\end{array}$ & $\begin{array}{l}\text { Adult patient } 56 \\
\text { years old confirmed } \\
\text { COVID-19 }\end{array}$ & $\begin{array}{l}\text { Hypertensi, obesity, } \\
\text { cancer, asthma, heart } \\
\text { disease, autoimmune, } \\
\text { COPD, and cancer }\end{array}$ & $\begin{array}{l}\text { Without } \\
\text { comorbid } \\
\text { asthma }\end{array}$ & Mortality & $\begin{array}{l}\mathrm{aOR}=1.62 \\
(0.22 \text { to } \\
7.52)\end{array}$ \\
\hline $\begin{array}{l}\text { Choi et al. } \\
(2020)\end{array}$ & $\begin{array}{l}\text { January to } 15 \\
\text { May } 2020\end{array}$ & Korea & $\begin{array}{l}\text { Retrospective } \\
\text { cohort }\end{array}$ & 7,590 & $\begin{array}{l}218 \\
(2.9)\end{array}$ & $\begin{array}{l}\text { Inpatients aged o-70 } \\
\text { year with COVID-19 } \\
\text { mild to severe } \\
\text { symptoms }\end{array}$ & Asthma & $\begin{array}{l}\text { Without } \\
\text { comorbid } \\
\text { asthma }\end{array}$ & Mortality & $\begin{array}{l}\mathrm{aOR}=1.32 \\
(0.71 \text { to } \\
2.45)\end{array}$ \\
\hline $\begin{array}{l}\text { Cummins } \\
\text { et al. } \\
(2021)\end{array}$ & $\begin{array}{l}1 \text { February to } \\
30 \text { June } \\
2020\end{array}$ & UK & $\begin{array}{l}\text { Retrospective } \\
\text { cohort }\end{array}$ & 1,781 & $\begin{array}{c}244 \\
(13 \cdot 7)\end{array}$ & $\begin{array}{l}\text { Adult patient aged } 16 \\
\text { years confirmed } \\
\text { COVID-19 }\end{array}$ & $\begin{array}{l}\text { obesity, asthma, cancer, } \\
\text { chronic heart disease, } \\
\text { COPD, Diabetes } \\
\text { mellitus, hypertension, } \\
\text { and stroke }\end{array}$ & $\begin{array}{l}\text { Without } \\
\text { comorbid } \\
\text { asthma }\end{array}$ & Mortality & $\begin{array}{l}\mathrm{aOR}=1.03 \\
(0.70 \text { to } \\
1.50)\end{array}$ \\
\hline $\begin{array}{l}\text { Ken-Dror } \\
\text { et al. } \\
(2020)\end{array}$ & $\begin{array}{l}\text { March to } \\
\text { April } 2020\end{array}$ & UK & $\begin{array}{l}\text { Prospective } \\
\text { cohort }\end{array}$ & 429 & $\begin{array}{c}42 \\
(12.8)\end{array}$ & $\begin{array}{l}\text { Adult patient aged } 70 \\
\text { years with confirmed } \\
\text { COVID-19 } \\
\text { hospitalized }\end{array}$ & Hypertensi and asthma & $\begin{array}{l}\text { Without } \\
\text { comorbid } \\
\text { asthma }\end{array}$ & Mortality & $\begin{array}{l}\mathrm{aOR}=3.22 \\
(1.16 \text { to } \\
8.92)\end{array}$ \\
\hline $\begin{array}{l}\text { Lee et al. } \\
(2020)\end{array}$ & $\begin{array}{l}20 \text { January } \\
\text { to } 27 \text { May } \\
2020\end{array}$ & UK & $\begin{array}{l}\text { Retrospective } \\
\text { cohort }\end{array}$ & 7,272 & $\begin{array}{c}686 \\
(9.4)\end{array}$ & $\begin{array}{l}\text { Adult patients aged } \\
20-70 \text { confirmed } \\
\text { year }\end{array}$ & $\begin{array}{l}\text { asthma, hypertension, } \\
\text { Diabetes mellitus, and } \\
\text { heart failure }\end{array}$ & $\begin{array}{l}\text { Without } \\
\text { comorbid } \\
\text { asthma }\end{array}$ & Mortality & $\begin{array}{l}\mathrm{aOR}=1.06 \\
(0.71 \text { to } \\
1.59)\end{array}$ \\
\hline $\begin{array}{l}\text { Lohia et } \\
\text { al. (2021) }\end{array}$ & $\begin{array}{l}\text { 10 March to } \\
\text { 30 June } \\
2020\end{array}$ & $\begin{array}{l}\text { United } \\
\text { States of } \\
\text { America }\end{array}$ & $\begin{array}{l}\text { Retrospective } \\
\text { cohort }\end{array}$ & 1,871 & $\begin{array}{c}134 \\
(7.2)\end{array}$ & $\begin{array}{l}\text { COVID-19 patient } \\
\text { age adult } 18 \text { years old } \\
\text { laboratory confirmed }\end{array}$ & $\begin{array}{l}\text { Hypertension, Diabetes } \\
\text { mellitus, asthma } \\
\text { kidney failure, cancer, } \\
\text { heart disease and stroke }\end{array}$ & $\begin{array}{l}\text { Without } \\
\text { comorbid } \\
\text { asthma }\end{array}$ & Mortality & $\begin{array}{l}\mathrm{aOR}=0.98 \\
(0.61 \text { to } \\
1.58)\end{array}$ \\
\hline $\begin{array}{l}\text { Mulhem } \\
\text { et al. } \\
(2020)\end{array}$ & $\begin{array}{l}13 \text { March to } \\
29 \text { April } \\
2020\end{array}$ & $\begin{array}{l}\text { United } \\
\text { States of } \\
\text { America }\end{array}$ & $\begin{array}{l}\text { Retrospective } \\
\text { cohort }\end{array}$ & 3219 & $\begin{array}{c}429 \\
(13 \cdot 3)\end{array}$ & $\begin{array}{l}\text { Inpatients aged } 65^{-} \\
85 \text { confirmed year } \\
\text { COVID-19 }\end{array}$ & $\begin{array}{l}\text { Diabetes mellitus, } \\
\text { hypertension, asthma, } \\
\text { COPD, chronic kidney } \\
\text { disease, and obesity }\end{array}$ & $\begin{array}{l}\text { Without } \\
\text { comorbid } \\
\text { asthma }\end{array}$ & Mortality & $\begin{array}{l}\mathrm{aOR}=1.14 \\
(0.84 \text { to } \\
1.55)\end{array}$ \\
\hline
\end{tabular}


Munawaroh et al./ Effect of Asthma Comorbidity on the Mortality of COVID-19 Patients

\begin{tabular}{|c|c|c|c|c|c|c|c|c|c|c|}
\hline \multirow{2}{*}{$\begin{array}{l}\text { Author } \\
\text { (Year) }\end{array}$} & \multirow{2}{*}{$\begin{array}{l}\text { Study } \\
\text { Period }\end{array}$} & \multirow[t]{2}{*}{ Country } & \multirow{2}{*}{$\begin{array}{c}\text { Study } \\
\text { Design }\end{array}$} & \multicolumn{2}{|c|}{ Sample Size } & \multirow{2}{*}{$\begin{array}{c}\mathbf{P} \\
\text { (Population) }\end{array}$} & \multirow{2}{*}{$\begin{array}{c}\text { I } \\
\text { (Intervention) }\end{array}$} & \multirow{2}{*}{$\begin{array}{c}\mathrm{C} \\
\text { (Comparison) }\end{array}$} & \multirow{2}{*}{$\begin{array}{c}\text { O } \\
\text { (Outcome) }\end{array}$} & \multirow{2}{*}{$\begin{array}{c}\text { aOR } \\
\text { (CI 95\%) }\end{array}$} \\
\hline & & & & Total & $\begin{array}{c}\text { Asma } \\
(\%)\end{array}$ & & & & & \\
\hline $\begin{array}{l}\text { Osibogun } \\
\text { et al. } \\
(2021)\end{array}$ & $\begin{array}{l}27 \text { February } \\
\text { to } 6 \text { July } \\
2020\end{array}$ & Nigeria & $\begin{array}{l}\text { Retrospective } \\
\text { cohort }\end{array}$ & 2,184 & $\begin{array}{c}45 \\
(2.1)\end{array}$ & $\begin{array}{l}\text { Inpatients aged 33- } \\
55 \text { years confirmed } \\
\text { COVID-19 }\end{array}$ & $\begin{array}{l}\text { Hypertension, Diabetes } \\
\text { mellitus, disease kidney } \\
\text { failure, cancer, and } \\
\text { asthma }\end{array}$ & $\begin{array}{l}\text { Without } \\
\text { comorbid } \\
\text { asthma }\end{array}$ & Mortality & $\begin{array}{l}\mathrm{aOR}=1.81 \\
(0.49 \text { to } \\
6.65)\end{array}$ \\
\hline $\begin{array}{l}\text { Park et al. } \\
(2020)\end{array}$ & $\begin{array}{l}15 \text { February } \\
\text { to } 24 \text { April } \\
2020\end{array}$ & Korea & $\begin{array}{l}\text { Retrospective } \\
\text { cohort }\end{array}$ & 2,269 & $\begin{array}{c}67 \\
(3.2)\end{array}$ & $\begin{array}{l}\text { Inpatient aged } 55 \\
\text { confirmed year } \\
\text { COVID-19 }\end{array}$ & $\begin{array}{l}\text { COPD, chronic kidney } \\
\text { disease, and asthma }\end{array}$ & $\begin{array}{l}\text { Without } \\
\text { comorbid } \\
\text { asthma }\end{array}$ & Mortality & $\begin{array}{l}\mathrm{aOR}=2.13 \\
(0.74 \text { to } \\
6.13)\end{array}$ \\
\hline $\begin{array}{l}\text { Robles- } \\
\text { Perez et } \\
\text { al. (2021) }\end{array}$ & $\begin{array}{l}\text { March to } \\
\text { December } \\
2020\end{array}$ & Mexico & $\begin{array}{l}\text { Retrospective } \\
\text { cohort }\end{array}$ & 75,595 & $\begin{array}{l}2403 \\
(3.2)\end{array}$ & $\begin{array}{l}\text { Adult patient }>65 \\
\text { confirmed year } \\
\text { COVID-19 being } \\
\text { treated at hospital }\end{array}$ & $\begin{array}{l}\text { Obesity, cancer, asthma, } \\
\text { chronic kidney disease, } \\
\text { diabetes mellitus, } \\
\text { and cancer }\end{array}$ & $\begin{array}{l}\text { Without } \\
\text { comorbid } \\
\text { asthma }\end{array}$ & Mortality & $\begin{array}{l}\mathrm{aOR}=0.96 \\
(0.51 \text { to } \\
1.79)\end{array}$ \\
\hline $\begin{array}{l}\text { Rosa et al. } \\
(2021)\end{array}$ & $\begin{array}{l}27 \text { February } \\
\text { to } 15 \text { June } \\
2020\end{array}$ & Italy & $\begin{array}{l}\text { Retrospective } \\
\text { cohort }\end{array}$ & 1,538 & $\begin{array}{c}23 \\
(1.5)\end{array}$ & $\begin{array}{l}\text { Social Security } \\
\text { Workers confirmed } \\
\text { COVID-19 61-83 } \\
\text { years old }\end{array}$ & $\begin{array}{l}\text { Diabetes mellitus, } \\
\text { hypertension, } \\
\text { cardiovascular, COPD } \\
\text { and } \\
\text { asthma }\end{array}$ & $\begin{array}{l}\text { Without } \\
\text { comorbid } \\
\text { asthma }\end{array}$ & Mortality & $\begin{array}{l}\mathrm{aOR}=1.45 \\
(0.44 \text { to } \\
4.78)\end{array}$ \\
\hline $\begin{array}{l}\text { Toples et } \\
\text { al. (2021) }\end{array}$ & $\begin{array}{l}\text { March } 16 \text { to } \\
\text { August } 24, \\
2020\end{array}$ & UK & $\begin{array}{l}\text { Retrospective } \\
\text { cohort }\end{array}$ & $\begin{array}{c}473,13 \\
9\end{array}$ & $\begin{array}{l}306 \\
(0.1)\end{array}$ & $\begin{array}{l}\text { COVID-19 confirmed } \\
\text { patients aged } 60-74 \\
\text { years who are } \\
\text { hospitalized }\end{array}$ & Asthma & $\begin{array}{l}\text { Without } \\
\text { comorbid } \\
\text { asthma }\end{array}$ & Mortality & $\begin{array}{l}\mathrm{aOR}=1.10 \\
(0.78 \text { to } \\
1.54)\end{array}$ \\
\hline $\begin{array}{l}\text { Trabulus } \\
\text { et al. } \\
(2021)\end{array}$ & $\begin{array}{l}15 \text { March to } 1 \\
\text { May } 2020\end{array}$ & Turkey & $\begin{array}{l}\text { Retrospective } \\
\text { cohort }\end{array}$ & 336 & $\begin{array}{c}20 \\
(6.0)\end{array}$ & $\begin{array}{l}\text { COVID-19 patient } \\
\text { age } 69 \text { year with } \\
\text { confirmation } \\
\text { laboratory }\end{array}$ & $\begin{array}{l}\text { Diabetes mellitus, } \\
\text { asthma, hypertension, } \\
\text { cancer, COPD and heart } \\
\text { disease }\end{array}$ & $\begin{array}{l}\text { Without } \\
\text { comorbid } \\
\text { asthma }\end{array}$ & Mortality & $\begin{array}{l}\mathrm{aOR}=3.09 \\
(0.38 \text { to } \\
24.96)\end{array}$ \\
\hline
\end{tabular}


Munawaroh et al./ Effect of Asthma Comorbidity on the Mortality of COVID-19 Patients

\section{DISCUSSION}

This systematic review and meta-analysis research raised the theme of the influence of asthma comorbidities on mortality in COVID-19 patients. The independent variable analyzed was asthma comorbidity. The dependent variable analyzed was COVID-19 mortality. This study discusses asthma comorbidities, this is considered important because it is considered a high risk group for the severity and even mortality of COVID-19 patients (CDC, 2020).

The primary studies that met the criteria were 15 articles from 3 Americas, 6 from Europe, 4 from Asia, and 1 from America. This study shows that asthma comorbidity is statistically significant in influencing mortality of COVID-19 patients. The forest plot results show the magnitude of the effect of comorbid asthma on mortality of COVID-19 patients, which is 1.18 increasing mortality of COVID-19 patients $(\mathrm{aOR}=1.18 ;$ CI $95 \%=1.02$ to $1.36 ; \mathrm{p}=$ o.030). The heterogeneity of the research data shows $\mathrm{I}^{2}=0 \%$ so that the distribution of the data is declared homogeneous (fixed effect model).

Asthma comorbidity may increase the risk of mortality in COVID-19 patients, these results are in accordance with the hypothesis. According to research Choi et al. (2020) showed that asthma is a risk factor for increased mortality in COVID-19 patients in Korea. The research of Choi et al. (2020) recommends that doctors advise asthma patients to routinely use asthma medications during the COVID-19 pandemic. This is supported by research by Lee et al. (2020) showed that asthmatic patients who had experienced an acute exacerbation prior to COVID-19 increased COVID-19 mortality. Research by Shin et al. (2021) showed that COVID-19 patients with asthma were more likely to be in critical condition requiring ventilation and have a higher risk of mortality.

The results of the study were in line with those conducted by Almazeedi et al. (2020) which stated that asthma comorbidity was a risk factor for mortality in COVID-19 patients in Kuwait $(\mathrm{aOR}=4.92$; CI $95 \%=1.03$ to $23.44 ; \mathrm{p}=0.046)$. Other similar studies were found in the UK (Fong et al., 2021), South America (Mato et al., 2020), Turkey (Trabulus et al., 2021) and Spain (Almirall et al., 2020).

The results of this study are not in line with Sunjaya et al. (2020) which showed that a $14 \%$ (CI $95 \%=0.80$ to 0.94 ) risk of contracting COVID-19 was lower in people with asthma. There are several possible explanations for the reduced risk of mortality, including the observation that people with high Th2 asthma can lower the angiotensin-converting-enzyme-2 (ACE-2) receptor, thereby reducing the risk of SARS-CoV2 infection (Jackson et al., 2020). Other evidence from the Asthma Research Program suggests that inhaled corticosteroid therapy is associated with lower ACE-2, which makes it harder for the virus to enter the body (Peters et al., 2020; Jakson et al., 2020). Interferon levels in asthmatics are hypothesized to be protective against the cytokine storm that occurs in COVID-19 patients (Carli et al., 2020). This can provide reduced susceptibility to COVID-19 and less severe disease progression.

Another inconsistent study conducted by Lee et al. (2021) who stated that comorbid asthma reduces the risk of COVID-19 mortality in Korea. Similar results were found in the United States (Arshad et al., 2020; Izurieta et al., 2021; Kelly et al., 2021; Yehia et al., 2020; Vaughn et al., 2021), France (Beltramo et al., 2020), Brazil (Castro et al., 2021), Ireland (Bennet et al., 2021), Belgium (Calmes et al., 2021), Mexico (Parra-Bracamonte., 2020; Martos 
Munawaroh et al./ Effect of Asthma Comorbidity on the Mortality of COVID-19 Patients

Benítez et al., 2021) and the UK (PerezGuzman et al., 2020; Atkins et al., 2020).

\section{AUTHOR CONTRIBUTION}

Siti Mar'atul Munawaroh is the main researcher who chooses the topic, searches for and collects research data. Hanung Prasetya and Bhisma Murti analyzed data and reviewed the research documents.

\section{FUNDING AND SPONSORSHIP}

This study is self-funded.

\section{CONFLICT OF INTEREST}

There is no conflict of interest in this study.

\section{ACKNOWLEDGEMENT}

We are very grateful to database providers PubMed, Google Scholar, and Scopus.

\section{REFERENCES}

Abrams EM, Szefler SJ (2020). Managing asthma during COVID-19: an example for other chronic conditions in children and adolescents. J Pediatr. 222: 221-226. https://doi.org/10.1016/j.jpeds.2020.04.049.

Almazeedi S, Al-Youha S, Jamal MH, AlHaddad M, Al-Muhaini A, Al-Ghimlas F, Al-Sabah S (2020). Characteristics, risk factors and outcomes among the first consecutive 1096 patients diagnosed with COVID-19 in Kuwait. EclinicalMedicine. 24 (2020): 100448. DOI: 10.1016/j.eclinm.2020.100448.

Almirall A, Kostov B, Mas-Heredia M, Vilanova-Rotllan S, Sequeira-Aymar E, Sans-Corrales M, Sant-Arderiu E, et al. (2020). Prognostic factors in Spanish COVID-19 patients: A case series from Barcelona. PLoS One. 15(8): e023796o. DOI: $10.1371 /$ journal.pone.0237960.

Arshad S, Kilgore P, Chaudhry ZS, Jacobsen G, Wang DD, Huitsing K, Brar I, et al (2020). Treatment with hydroxychloroquine, azithromycin, and combination in patients hospita-lized with COVID-19. Int J Infect Dis. 97: 396-403. DOI: 10.1016/j.ijid.-2020.06.099. Atkins JL, Masoli JAH, Delgado J, Pilling LC, Kuo CL, Kuchel GA, Melzer D (2020). Preexisting Comorbidities Predicting COVID-19 and Mortality in the UK Biobank Community Cohort. J Gerontol A Biol Sci Med Sci. 75(11): 2224-2230. DOI: 10.1093/ge-rona/glaa183.

Beltramo G, Cottenet J, Mariet AS, Georges M, Piroth L, Tubert-Bitter P, Bonniaud $\mathrm{P}$, et al. (2021). Chronic respiratory diseases are predictors of severe outcome in COVID-19 hospitalised patients: a nationwide study. Eur Respir J. 2004474. DOI: 10.1183/13993003.04474-2020.

Bennett KE, Mullooly M, O'Loughlin M, Fitzgerald M, O'Donnell J, O'Connor L, Oza A, et al. (2021). Underlying conditions and risk of hospitalisation, ICU admission and mortality among those with COVID-19 in Ireland: a national surveillance study. Lancet Reg Health Eur. 100097. DOI: 10.1016/j.lanepe.2021.100097.

Calmes D, Graff S, Maes N, Frix AN, Thys $\mathrm{M}$, Bonhomme O, Berg J, et al. (2020) Asthma and copd are not risk factors for icu stay and death in case of sarscov2 infection. J Allergy Clin Immunol Pract. 9(1): 160-169. DOI: 10.1016/j.jaip.2020.09.044.

Carli G, Cecchi L, Stebbing J, Parronchi P, Farsi A (2021). Is asthma protective against COVID-19? Allergy. 2021(76): 866-936. DOI: 10.1111/all.14426.

Castro MC, Gurzenda S, Macário EM, França GVA (2021). Characteristics, outcomes and risk factors for mortality of 522167 patients hospitalised 
Munawaroh et al./ Effect of Asthma Comorbidity on the Mortality of COVID-19 Patients

with COVID-19 in Brazil: a retrospective cohort study. BMJ Open. 11(5): e049089. DOI: 10.1136/bmjopen-2021-049089.

Centers for Disease Control and Prevention (2020). Coronavirus disease 2019 (COVID-19). Retrieved from: https://www.cdc.gov/coronavirus/2019-ncov/need-extra-precautions/peopleat-higher-risk.html.

Charoenngam N, Alexanian SM, Apovian CM, Holick MF (2020). Association between hyperglycemia at hospital presentation and hospital outcomes in covid-19 patients with and without type 2 diabetes: a retrospective cohort study of hospitalized inner-city COVID-19 patients. Nutrients. 13(7): 2199. DOI: 10.3390/nu13072199.

Chen N, Zhou M, Dong X, Qu J, Gong F, Han Y, Qiu Y et al. (2020). Epidemiological and clinical characteristics of 99 cases of 2019 novel coronavirus pneumonia in Wuhan, China: a descriptive study. Lancet. 395-(10223): 507-513. DOI: 10.1016/So140-6736(20)30211-7.

Choi YJ, Park JY, Lee HS, Suh J, Song JY, Byun MK, Cho JH, et al. (2020). Effect of asthma and asthma medication on the prognosis of patients with COVID-19. Eur Respir J. 57(3): 2002226. DOI: $10.1183 / 13993003.02226-$ 2020.

Corcoles A, Satue-Graciaa E, Vila-Rovirab A, Diego-Cabanesa C, Forcadell-Perisa MJ, Ochoa-Gondar O (2020). Development of a predictive prognostic rule for early assessment of COVID-19 patients in primary care settings. Atencion Primaria. 53 (2021): 102118. https://doi.org/10.1016/j.aprim.2021.102118.

Cummins L, Ebyarimpa I, Cheetham N, Tzortziou Brown V, Brennan K,
Panovska-Griffiths J (2021). Factors associated with COVID-19 related hospitalisation, critical care admission and mortality using linked primary and secondary care data. Influenza Other Respir Viruses. 15(5): 577-588. DOI: 10.1111/irv.12864.

Fang X, Li S, Yu H, Wang P, Zhang Y, Chen Z, Li Y, et al. (2020). Epidemiological, comorbidity factors with severity and prognosis of COVID-19: A systematic review and meta-analysis. Aging. 12(13): 12493-12503. DOI: 10.18632/aging.103579.

Fong WCG, Borca F, Phan H, Moyses HE, Dennison P, Kurukulaaratchy RJ, Haitchi HM (2021). Asthma did not increase in-hospital COVID-19-related mortality in a tertiary UK hospital. Clin Exp Allergy. 51(7): 939-941. DOI: 10.1111/cea.13855.

G, Greco M, Zanella A, Albano G, Antonelli M, Bellani G, Bonanomi E, et al. (2020). Risk factors associated with mortality among patients with covid19 in intensive care units in Lombardy, Italy. JAMA Intern Med. 180(10): 1345-1355. DOI: 10.1001/jamainternmed.2020.3539.

Huang $\mathrm{K}$, Yang $\mathrm{T}$, Xu J, Yang L, Zhao J, Zhang X, Bai C, et al. (2019). Prevalence, risk factors, and management of asthma in China: a national crosssectional study. Lancet. 394(10196): 407-418. DOI: 10.1016/So140-6736(19)31147-X.

Huang C, Wang Y, Li W, Ren L, Zhao J, Hu $\mathrm{Y}$, Zang L, et al. (2020). Clinical features of patients infected with 2019 novel coronavirus in Wuhan, China. Lancet. 395(10223): 497-506. DOI: 10.1016/So140-6736(20)30183-5.

Izurieta HS, Graham DJ, Jiao Y, Hu M, Lu $\mathrm{Y}, \mathrm{Wu}$ Y, Chillarige Y, Wernecke et al. (2021). Natural history of coronavirus 
Munawaroh et al./ Effect of Asthma Comorbidity on the Mortality of COVID-19 Patients

disease 2019: risk factors for hospitalizations and deaths among $>26$ million us medicare beneficiaries. J Infect Dis. 223(6): 945-956. DOI: 10.1093/infdis/jiaa767.

Jackson DJ, Busse WW, Bacharier LB, Kattan M, O'Connor GT, Wood RA, Visness CM, et al. (2020). Association of respiratory allergy, asthma, and expression of the SARS-CoV-2 receptor ACE2. J Allergy Clin Immunol. 146(1): 203-206.e3. DOI: 10.1016/j.jaci.2020.04.009.

Kar S, Chawla R, Haranath SP, Ramasubban S, Ramakrishnan N, Vaishya $\mathrm{R}$, Sibal A, et al. (2020). Multivariable mortality risk prediction using machine learning for COVID 19 patients at admission (AICOVID). Sci Rep. 11(12801). https://doi.org/10.1038/s41598-021-92146-7.

Kelly JD, Bravata DM, Bent S, Wray CM, Leonard SJ, Boscardin WJ, Myers LJ, et al. (2021). Association of social and behavioral risk factors with mortality among US veterans with COVID-19. JAMA network open. 4(6): e2113031. https://DOI.org/10.1001/jamanetworkopen.2021.13031

Ken-Dror G, Wade C, Sharma S, Law J, Russo C, Sharma A, Joy E, et al. (2020). COVID-19 outcomes in UK centre within highest health and wealth band: a prospective cohort study. BMJ Open. 10(11): e042090. DOI: 10.1136/bmjopen-2020-042090.

Kim D, Adeniji N, Latt N, Kumar S, Bloom PP, Aby ES, Perumalswami P (2021). Predictors of Outcomes of COVID-19 in Patients with Chronic Liver Disease: US Multi-center Study. Clin Gastroenterol Hepatol. 19(7): 1469-1479. https://doi.org/10.1016/j.cgh.2020.09.027.

Kurniawati O, Prasetya H, Murti B (2021).
Meta-analysis the effects of obesity and type 2 diabetes mellitus on covid19 mortality. J Epidemiol Public Health. 06(02): 177-191. https://doi.org/10.26911/jepublichealth.2021.06.02.0 5 .

La-Pena JE, Rascon-Pacheco RA, AscencioMontiel IJ, Gonzalez-Figueroa E, Fernandez-Garate JE, Medina-Gomez OS, Borja-Bustamante P (2021). Hypertension, diabetes and obesity, major risk factors for death in patients with COVID-19 in Mexico. Arch Med Res. 52(4): 443-449. DOI: 10.1016/j.arcmed.2020.12.002.

Lee SC, Son KJ, Han CH, Jung JY, Park S (2020). Impact of comorbid asthma on severity of coronavirus disease (COVID-19). Sci Rep. 2020(10): 21805. DOI: 10.1038/s41598-020-77791-8.

Lohia P, Sreeram K, Nguyen P, Choudhary A, Khicher S, Yarandi H, et al. (2021). Preexisting respiratory diseases and clinical outcomes in COVID-19: a multihospital cohort study on predominantly African American population. Respir Res. 2021(22): 37. DOI: 10.1186/s12931-021-01647-6.

Li X, Xu S, Yu M, Wang K, Tao Y, Zhou Y, Tao Y, et al. (2020). Risk factors for severity and mortality in adult COVID-19 inpatients in Wuhan. J Allergy Clin Immunol. 110-118. https://doi.org/10.1016/j.jaci.2020.04.006.

Martos-Benítez FD, Soler-Morejón CD, García-Del Barco D (2021). Chronic comorbidities and clinical outcomes in patients with and without COVID19: a large population-based study using national administrative healthcare open data of Mexico. Intern Emerg Med. 16(6): 1507-1517. DOI: 10.1007/s11739-020-02597-5.

Mato AR, Roeker LE, Lamanna N, Allan JN, Leslie L, Pagel JM, Patel K, et al. 
Munawaroh et al./ Effect of Asthma Comorbidity on the Mortality of COVID-19 Patients

(2020). Outcomes of COVID-19 in patients with CLL: a multicenter international experience. Blood. 136(10): 1134-1143. DOI: 10.1182/blood.2020006965.

Mulhem E, Oleszkowicz A, Lick D (2021). 3219 hospitalised patients with COVID-19 in Southeast Michigan: a retrospective case cohort study. BMJ Open 2021(11): e042042. DOI: 10.1136/bmjopen-2020-042042.

Osibogun A, Balogun M, Abayomi A, Idris J, Kuyinu Y, Odukoya O, et al. (2021). Outcomes of COVID-19 patients with comorbidities in southwest Nigeria. PLoS One 2021(16): eo248281. https://DOI.org/10.1371/journal.pon e.0248281.

Park BE, Lee JH, Park HK, Kim HN, Jang SY, Bae MH, Yang DH, et al. (2021). Impact of cardiovascular risk factors and cardiovascular diseases on outcomes in patients hospitalized with COVID-19 in Daegu Metropolitan City. J Korean Med Sci. 36(2): e15. DOI: 10.3346/jkms.2021.36.e15.

Parra-Bracamonte GM, Lopez-Villalobos N, Parra-Bracamonte FE (2020). Clinical characteristics and risk factors for mortality of patients with COVID-19 in a large data set from Mexico. Ann Epidemiol. 2020(52): 93-98.e2. DOI: 10.1016/j.annepide-m.2020.08.005.

Perez-Guzman PNP, Daunt A, Mukherjee S, Crook P, Forlano R, Kont MD, et al. (2020). Clinical characteristics and predictors of outcomes of hospitalized patients with coronavirus disease 2019 in a multiethnic london national health service trust: a retrospective cohort study. Clin Infect Dis. 2020 (ciaa1091): 1-11. https://DOI.org/10.1093/cid/-ciaa1091.

Peters MC, Sajuthi S, Deford P, Christenson S, Rios CL, Montgomery MT, Wood- ruff PG, et al. (2020). COVID-19-related Genes in Sputum Cells in Asthma. Relationship to Demographic Features and Corticosteroids. Am J Respir Crit Care Med. 202(1): 83-90. DOI: 10.1164/rccm.202003-0821OC.

Robles-Pérez E, González-Díaz B, MirandaGarcía M, Borja-Aburto VH (2021). Infection and death by COVID-19 in a cohort of healthcare workers in Mexico. Scand J Work Environ Health. 47(5): 349-355. DOI: 10.5271/sjweh.3970 .

Rosa FG, Palazzo A, Rosso T, Shbaklo N, Mussa M, Boglione L, et al. (2021). Risk factors for mortality in COVID19 hospitalized patients in Piedmont, Italy: results from the multicenter, regional, CORACLE registry. J. Clin. Med. 10(9): 1951. https://DOI. org/10.3390/jcm10091951

Ruan Q, Yang K, Wang W, Jiang L, Song J (2020). Clinical predictors of mortality due to COVID-19 based on an analysis of data of 150 patients from Wuhan, China. Intensive Care Med. 46: 846-848. DOI: 10.1007- /soo134020-05991-X.

Shi S, Qin M, Shen B, Cai Y, Liu T, Yang, Gong W, et al. (2021). Association of cardiac injury with mortality in hospitalized patients with covid-19 in $\mathrm{Wu}-$ han, China. JAMA Cardiol. 5(7): 802810. DOI:10.1001/jamacardio.2020.0950.

Shin EK, Choi HY, Hayes N (2021). The anatomy of COVID-19 comorbidity networks among hospitalized Korean patients. Epidemiol Health. 2021(43): e2021035. DOI: 10.4178/epih.e2021035.

Song J, Park DW, Cha J, Seok H, Kim JY, Park J, Cho H (2020). Clinical course and risk factors of fatal adverse outcomes in COVID 19 patients in 
Munawaroh et al./ Effect of Asthma Comorbidity on the Mortality of COVID-19 Patients

Korea: a nationwide retrospective cohort study. Sci Rep. 11(10066). DOI: 10.1038/s41598-021-89548-y.

Sticchi A, Cereda A, Toselli M, Esposito A, Palmisano A, Vignale D, Nicoletti V, et al. (2021). Diabetes and mortality in patients with COVID-19: Are we missing the link? Anatol J Cardiol. 25(6): 376-9 DOI: 10.5152/AnatolJCardiol.2021.29132.

Sun Y, Guan X, Jia L, Xing N, Cheng L, Liu $\mathrm{B}$, Zhang S, et al. (2020). Independent and combined effects of hypertension and diabetes on clinical outcomes in patients with COVID-19: A retrospective cohort study of Huoshen Mountain Hospital and Guanggu Fangcang Shelter Hospital. J Clin Hypertens. 2021(23): 218-231. DOI: 10.1111/jch.14146.

Sunjaya AP, Allida SM, Di Tanna GL, Jenkins C (2021). Asthma and risk of infection, hospitalization, ICU admission and mortality from COVID-19: Systematic review and meta-analysis. J Asthma. 1:1-14. DOI: 10.1080/02770903.2021.1888116.

Topless RK, Phipps-Green A, Leask M, Dalbeth N, Stamp LK, Robinson PC, Merriman TR (2021). Gout, rheumatoid arthritis, and the risk of death related to coronavirus disease 2019: an analysis of the UK Biobank. ACR Open Rheumatol. 3(5): 333-340. DOI: 10.1002/acr2.11252.

Trabulus S, Karaca C, Balkan II, Dincer MT, Murt A, Ozcan SG, Karaali R, et al. (2020). Kidney function on admission predicts in-hospital mortality in COVID-19. PLoS One. 15(9): eo23868o. DOI: 10.1371/journal.pone.0238680.

Vaughn VM, Gandhi TN, Petty LA, Patel PK, Prescott HC, Malani AN, Ratz D, et al. (2021). Empiric antibacterial therapy and community-onset bacterial coinfection in patients hospitalized with coronavirus disease 2019 (COVID-19): a multi-hospital cohort study. Clin Infect Dis. 72(10): e533e541. DOI: 10.1093/cid/ciaa1239.

WHO (2020a). COVID-19 Weekly Epidemiological Update 22. World Health Organization. 1-3. Retrieved from: https://www.who.int/docs/-defaultsource/coronaviruse/situation-reports/weekly_epidemio-logical_update_22.- pdf.

Williamson EJ, Walker AJ, Bhaskaran K, Bacon S, Bates S, Morton CE, Curtis HJ (2020). Factors associated with COVID-19-related death using OpenSAFELY. Nature. 584: 430-436. https://doi.org/10.1038/s4158-6-02o-2521-4

Xu X, Yu C, Qu J, Zhang L, Jiang S, Huang $\mathrm{D}$, Chen B, et al. (2020). Imaging and clinical features of patients with 2019 novel coronavirus SARS-CoV-2. Eur J Nucl Med Mol Imaging. 47(5): 12751280. DOI: $10.1007 /$ s00259-020-04735-9.

Yehia BR, Winegar A, Fogel R, Fakih M, Ottenbacher A, Jesser C, Bufalini A, et al. (2020). Association of race with mortality among patients hospitalized with coronavirus disease 2019 (COVID-19) at 92 US Hospitals. JAMA Netw Open. 3(8): e2018039. DOI: 10.1001-/jamanetworkopen.2020.18039

Zhou F, Yu T, Du R, Fan G, Liu Y, Liu Z, Xiang J, et al. (2020). Clinical course and risk factors for mortality of adult inpatients with COVID-19 in Wuhan, China: a retrospective cohort study. Lancet. 395(10229): 1054-1062. DOI: 10.1016/So140-6736(20)30566-3. 